\title{
Potato Zebra Chip: An Overview of the Disease, Control Strategies, and Prospects
}

\author{
Victoria Mora', Manikandan Ramasamy', Mona B. Damaj', Sonia Irigoyen', \\ Veronica Ancona ${ }^{2}$, Freddy Ibanez ${ }^{1,3}$, Carlos A. Avila ${ }^{1,4}$ and Kranthi K. Mandadi 1,5* \\ ${ }^{1}$ Texas A\&M Agrilife Research and Extension Center, Weslaco, TX, United States, ${ }^{2}$ Department of Agriculture, Agribusiness, \\ and Environmental Sciences, Citrus Center, Texas A\&M University-Kingsville, Weslaco, TX. United States, ${ }^{3}$ Department \\ of Entomology, Minnie Bell Heep Center, Texas A\&M University, College Station, TX, United States, ${ }^{4}$ Department \\ of Horticultural Sciences, Texas A\&M University, College Station, TX, United States, ${ }^{5}$ Department of Plant Pathology \\ and Microbiology, Texas A\&M University, College Station, TX, United States
}

OPEN ACCESS

Edited by:

Milko Alberto Jorquera, University of La Frontera, Chile

Reviewed by:

Gary Secor:

North Dakota State University,

United States

Jessica Vereijssen,

The New Zealand Institute for Plant and Food Research Ltd, New Zealand Karin Cruzado

University of Idaho, United States

${ }^{*}$ Correspondence:

Kranthi K. Mandadi kkmandadi@tamu.edu

Specialty section:

This article was submitted to Microbe and Virus Interactions with

Plants,

a section of the journal Frontiers in Microbiology

Received: 26 April 2021 Accepted: 30 June 2021

Published: 22 July 2021

Citation:

Mora V, Ramasamy $M$,

Damaj MB, Irigoyen S, Ancona V Ibanez F, Avila CA and Mandadi KK

(2021) Potato Zebra Chip: An Overview of the Disease, Control

Strategies, and Prospects.

Front. Microbiol. 12:700663. doi: 10.3389/fmicb.2021.700663
Potato (Solanum tuberosum L.) is an important food crop worldwide. As the demand for fresh and processed potato products is increasing globally, there is a need to manage and control devastating diseases such as zebra chip (ZC). ZC disease causes major yield losses in many potato-growing regions and is associated with the fastidious, phloemlimited bacterium Candidatus Liberibacter solanacearum (CLso) that is vectored by the potato-tomato psyllid (Bactericera cockerelli Šulc). Current management measures for ZC disease mainly focus on chemical control and integrated pest management strategies of the psyllid vector to limit the spread of CLso, however, they add to the costs of potato production. Identification and deployment of CLso and/or the psyllid resistant cultivars, in combination with integrated pest management, may provide a sustainable long-term strategy to control ZC. In this review, we provide a brief overview of the ZC disease, epidemiology, current management strategies, and potential new approaches to manage ZC disease in the future.

Keywords: Fastidious bacteria, zebra chip, psyllids, Candidatus Liberibacter solanacearum, Solanaceae, Resistant varieties, crop improvement

\section{INTRODUCTION}

Potatoes (Solanum tuberosum L.) constitute a centuries-old world dietary staple, with total world production estimated at 368.2 million tons in 2018 (Faostat, 2020). The United States is the fifth largest potato producer, after China, India, Russia, and Ukraine (Faostat, 2020), with an industry valued at $\sim 3.5$ billion (USDA, 2019; Faostat, 2020). About one-third of United States grown potatoes are for processing, of which $63-83 \%$ are for frying, chipping and other packaged products, and the rest for fresh market, fodder, or used as seed (USDA, 2019). Potato domestication resulted in cultivars with reduced glycoalkaloid tuber content, making them more palatable and leading to increased tuber size and improved carbon fixation and transport (Spooner et al., 2014; Machida-Hirano, 2015). Few hardy wild potatoes were also crossed with their cultivated relatives to improve disease resistance, yield and quality for almost a century (Jansky et al., 2013). This yielded highly marketable improvements, like enhanced processing quality for chipping and frying, and resistance to some viruses and nematodes (Douches et al., 1996; Hirsch et al., 2013; Bethke et al., 2017). However, their low genetic diversity led to vulnerability to pests and diseases, and acute inbreeding depression. 


\section{EARLY REPORTS OF ZEBRA CHIP DISEASE}

Zebra chip (ZC) disease was first reported in 1994 in Saltillo, Mexico, and later in South Texas, United States in 2000 (Munyaneza et al., 2007, 2009), The fastidious phloem-limited bacterium, Candidatus Liberibacter solanacearum (CLso), was identified as a putative causal agent. CLso is transmitted to plants by the potato-tomato psyllid Bactericera cockerelli Sulc (Munyaneza et al., 2007; Hansen et al., 2008; Liefting et al., 2009). Vegetative symptoms of ZC disease on plants include leaf chlorosis, discoloration, curling or upward rolling, aerial tubers, axillary bud proliferation, stunted growth, and eventually premature plant death (Figure 1). CLso-infected potato tubers are often deformed and of poor quality, exhibiting collapsed stolons, vascular ring browning and brown flecks. When fried for chipping, the brown discoloration becomes darker, making chips bitter to taste, and unmarketable (Figure 1D; Secor and Rivera-Varas, 2004). Beyond North America, ZC disease is also documented in South America, New Zealand, and Australia (Hansen et al., 2008; Liefting et al., 2008a, 2009; Teulon et al., 2009; Crosslin et al., 2012; Munyaneza, 2012; Vereijssen et al., 2018).

Despite the relatively recent origins of ZC, potato psyllid infestation was first documented in peppers in Colorado, United States and was described as a potential pest in 1909 by Šulc (1909). The detrimental effects of psyllids were not fully noticed until 1927, when vast outbreaks of what was then described as psyllid yellows (PY) disease led to reduction of potato yields in Utah to the Rocky Mountain states of the United States (Linford, 1928; Richards, 1928). The description of the PY foliar symptoms (Arslan et al., 1985) was very similar to the foliar symptoms of ZC (Pitman et al., 2011; Figure 1). Although initially PY was thought to be associated with toxins released by psyllid feeding, so far, no other pathogens nor toxins have been associated with PY. Hence it led to a hypothesis that PY could be a mild case of ZC, wherein CLso was present at low, undetectable levels in the affected plants (Richards and Blood, 1933; Carter, 1939; Arslan et al., 1985; Munyaneza et al., 2011; Monger and Jeffries, 2018).

Nevertheless today, the potato psyllid is considered an A1 quarantine pest by the EPPO (European and Mediterranean Plant Protection Organization), and as a primary vector for CLso, together cause significant economic losses (PM, 2017).

\section{CLSO-POTATO PSYLLID HOST RANGE, TRANSMISSION, AND DIAGNOSTICS}

In addition to causing ZC disease on potatoes, CLso can be transmitted to and infect other solanaceous crops such as tomato (S. lycopersicum), tomatillo (Physalis spp.), eggplant (S. melongena), pepper (Capsicum spp.), tobacco (Nicotiana tabacum), and tamarillo (Solanum betaceum; Hansen et al., 2008; Liefting et al., 2008b, 2009; Munyaneza et al., 2009, 2013, 2014; Aguilar et al., 2013). B. cockerelli is the main CLso vector to infect these solanaceous crops in Mexico, United States, Central America (Guatemala, Honduras, and Nicaragua), Ecuador,
Canada, New Zealand, and Australia (Liefting et al., 2008a; Munyaneza et al., 2009; Bextine et al., 2013; Thomas et al., 2018; Carrillo et al., 2019; Henrickson et al., 2019). Few wild solanaceous species can serve as a reservoir for both $B$. cockerelli and CLso (Henne et al., 2010; Murphy et al., 2014; Vereijssen et al., 2015). Studies have found certain psyllid haplotypes (Northwestern Haplotype) can overwinter on natural vegetations such as bittersweet nightshade (Solanum dulcamara L.; Murphy et al., 2013, 2014; Horton et al., 2015) and can remerge in the Summer to infect agronomic crops. Similarly, in New Zealand, both CLso and B. cockerelli were found on bittersweet nightshade and thorn-apple (Datura stramonium; Vereijssen et al., 2015). Further studies to determine specific CLso haplotypes prevalent in the wild species and weedy plants will provide new insights into the significance of reservoir hosts in CLso and ZC epidemiology (Bradshaw and Ramsay, 2005).

Feeding on infected plants is the main mode of CLso acquisition by adult psyllids and nymphs (Buchman et al., 2011). After acquisition, there is a 2 -week latent period before the infected psyllid is able to transmit the bacterium into new plant tissues (Sengoda et al., 2013). Upon feeding on a plant, it takes as little as $1 \mathrm{~h}$ for CLso to be transmitted into plant tissues (Buchman et al., 2011). Subsequently, depending on the host plant, it can take approximately 3 weeks for the onset of ZC symptoms (Charkowski et al., 2020). Within an infected plant, CLso is not evenly distributed and as such is present in low levels (Charkowski et al., 2020). Polymerase chain reaction (PCR) and/or quantitative PCR is the most widely used diagnostic approach for detecting CLso in both the host plants and the psyllids, and can be used to distinguish the different haplotypes (Hansen et al., 2008; Secor et al., 2009; Swisher et al., 2012; Ananthakrishnan et al., 2013; Beard and Scott, 2013; Beard et al., 2013; Contreras-Rendón et al., 2020). Other emerging technologies such as Raman Spectroscopy are also being explored to detect ZC disease, that allows for rapid, non-invasive and in-field diagnostics (Farber et al., 2021).

\section{CLSO HAPLOTYPES AND DIVERSITY}

Twelve different CLso haplotypes have been reported so far [A, B, C, D, F, G, H, H (Con), U, Cras1 and Cras2] (Wen et al., 2009; Munyaneza et al., 2010; Nelson et al., 2011, 2013; Teresani et al., 2014; Haapalainen et al., 2018, 2020; Mauck et al., 2019; Swisher Grimm and Garczynski, 2019; Contreras-Rendón et al., 2020; Sumner-Kalkun et al., 2020). In addition to B. cockerelli, other relatives in the Triozidae family (Hemiptera) transmit certain CLso haplotypes. For example, haplotype $\mathrm{C}$ found in carrots is vectored by Trioza apicalis Förster (Munyaneza et al., 2010). Haplotypes D and E are transmitted by the carrot psyllid vector, Bactericera trigonica Hodkinson (Nelson et al., 2011; Swisher et al., 2014; Borges et al., 2017; Charkowski et al., 2020). While, CLso haplotype U identified in northern Europe, is associated to Trioza urticae psyllid (Haapalainen et al., 2018). In the Americas, $\mathrm{ZC}$ disease is primarily associated with the haplotypes A, B, and F. CLso A and B are transmitted by $B$. cockerelli, while the vector of haplotype $\mathrm{F}$ is still unknown 


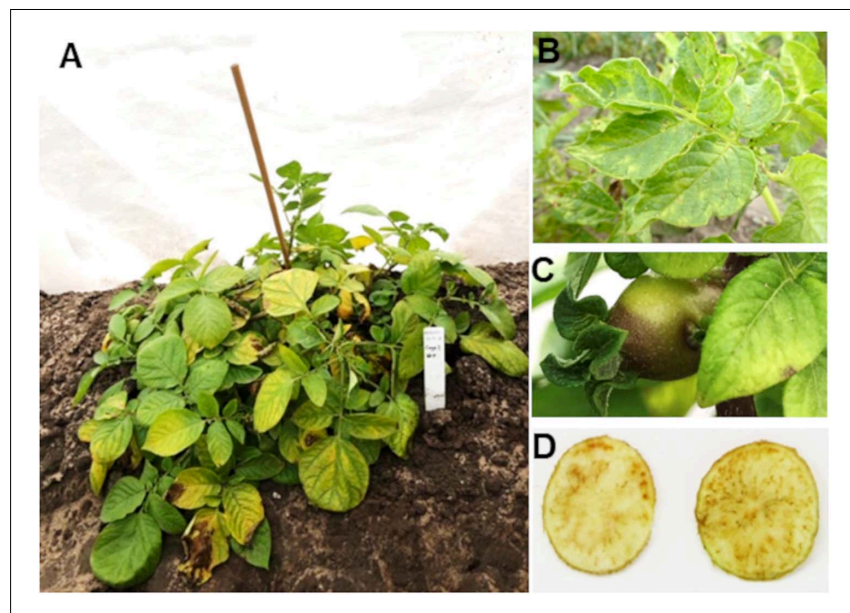

FIGURE 1 | Characteristic symptoms of zebra chip (ZC) disease. Infection of Candidatus Liberibacter solanacearum (CLso) often results in $\mathbf{( A , B})$ chlorosis and upward curling/rolling of leaves, stunted plants, (C) aerial tuber growth, and (D) necrotic flecking/browning of tubers/chips and overall reduction of marketable yield.

(Hansen et al., 2008; Wen et al., 2009; Nelson et al., 2011; Swisher Grimm and Garczynski, 2019). In New Zealand and Norfolk Island (Australia) the CLso haplotype A vectored by B. cockerelli interaction is considered the predominant haplotype causing ZC disease (Liefting et al., 2008a; Nelson et al., 2011; Thomas et al., 2018). Taken together, CLso haplotypes A and B appear to be the most predominant across the world, in the Americas, New Zealand, and Australia, and associated with the ZC disease in potatoes (Rosson et al., 2006; Liefting et al., 2008a; Nelson et al., 2011; Thomas et al., 2018; Savary et al., 2019; Delgado et al., 2020).

Studies with CLso haplotypes A and B showed that both haplotypes can infect plants either individually, or as coinfections (Harrison et al., 2019). Haplotype distribution and resulting effects on disease severity in single or co-infections were also studied in tomatoes and potatoes (Mendoza-Herrera et al., 2018; Harrison et al., 2019). For instance, infection of haplotype B is detrimental to tomato plants, as they usually die before fruit development, whereas plants can remain alive with symptoms when infected with haplotype A (MendozaHerrera et al., 2018). In potatoes, haplotype B induces greater ZC symptoms in tubers than haplotype A (Grimm et al., 2018), and dual-haplotype $\mathrm{AB}$ infections usually result in greater severe symptoms than infections with only haplotype B (HernándezDeheza et al., 2018; Harrison et al., 2019). Interestingly, haplotype B seems to lower psyllid nymph survival rate, compared to those carrying haplotype A (Yao et al., 2016).

\section{ZC CONTROL: PSYLLID MONITORING, CHEMICAL, BIOLOGICAL AND INTEGRATED PEST MANAGEMENT}

Currently, a primary approach to manage ZC is by controlling the psyllid vector populations. Components of integrated pest management (IPM) such as chemical, cultural, and biocontrol strategies have been implemented worldwide (Vereijssen et al., 2018). Extensive monitoring and detection of psyllid population are also being used to determine psyllid movements (Butler and Trumble, 2012). Data gathered from monitoring psyllids on sweep nets are correlated with psyllid-vectored diseases in tomato fields (Pletsch, 1947; Cranshaw, 1994). Generally, psyllid infestations start along the perimeter of a field, moving toward the center as their population increases (Wallis, 1955; Cranshaw, 1994). Evidence of psyllid infestation can also be obtained by leaf examination, though tedious and time consuming (Pletsch, 1947; Goolsby et al., 2007). While, other studies have found sticky traps to be useful for monitoring psyllid populations, even at low densities (Goolsby et al., 2007).

For psyllid control, pesticide use has been the main course of action in several regions. Typical pest management guidelines for potato psyllids include the application of neonicotinoids like imidacloprid and thiamethoxam at planting as a seed treatment, with a subsequent foliar application to control adults and nymphs (Prager et al., 2013; Vereijssen et al., 2015; Nuñez et al., 2019). Unfortunately, excessive use of pesticides led to incidences of neonicotinoid resistance in Southwestern United States, South Texas, and Northern Mexico (Prager et al., 2013; Chávez et al., 2015; Szczepaniec et al., 2019). As such pesticide reliance is both economically and environmentally unsustainable.

Some cultural methods for the control of psyllids have also been tested. Such as by using certified clean seed, and planting non-host plants in crop rotations to maintain disease free planting areas (Vereijssen et al., 2018). In warmer climates such as in Southern United States, planting dates could be altered to delay exposure to potato psyllids (Guenthner et al., 2012). Few organic farmers have also found some success using physical barriers such as mesh covers to lower psyllid infestations (Merfield et al., 2015).

Lastly, biocontrol strategies have also been employed. Natural enemies of the psyllid, such as ectoparasitoids, coccinellids, and entomopathogenic fungi have shown promising effects against psyllids, by parasitizing them at multiple life stages, in greenhouse and laboratory studies (Al-Jabr, 1999; MacDonald et al., 2010; Lacey et al., 2011; Walker et al., 2011; Mauchline and Stannard, 2013; Rojas et al., 2015). Deployment of such natural enemies as biocontrol agents in greenhouse production systems (e.g., tomato) or in the field-scale (e.g., potato) could allow growing an earlier crop and reduce reliance on insecticides.

\section{HOST PLANT RESISTANCE AND BREEDING STRATEGIES FOR ZC RESISTANCE}

Efforts were made to study host plant resistance toward developing ZC resistant potato cultivars. Plants employ different mechanisms to protect themselves against pathogens and insects. Some host-plant resistance mechanisms are constitutive, such as physical or pre-formed structural barriers and release of chemicals that disrupt pathogen transmission, insect feeding, and oviposition. Other plant defenses, such as volatile compounds emission or upregulation of resistance genes can also be triggered 
in response to a pest or pathogen (Dicke and Van Poecke, 2002; War et al., 2012). The host resistance mechanisms to pests can also be categorized as antixenosis and antibiosis. Generally, antixenosis refers to a deterring effect that plants can have on insect behavior, where antibiosis affects their lifecycle and reproduction (Painter, 1951; Kogan and Ortman, 1978; Smith, 2005).

In the case of $\mathrm{ZC}$, several varieties of potato and potato hybrids were identified to possess some degree of tolerance to $\mathrm{ZC}$ disease. In some varieties, tolerance was attributed to the antixenotic effects of glandular trichomes (Butler et al., 2011; Diaz-Montano et al., 2014; Rubio-Covarrubias et al., 2017). While few varieties appear to have a genetic basis for tolerance to CLso in addition to having effects on the psyllid behavior (Rashidi et al., 2017; Fife et al., 2020). Recently, few wild-relatives of tomato, S. pennelli, and S. corneliomulleri were identified to possess resistance to B. cockerelli (Avila et al., 2019), with several quantitative trait loci (QTL) associated with insect mortality and lower fecundity in S. habrochaites. Such QTL in wild species could be a valuable source for breeding resistance to cultivars, however, their complex inheritance, modes of action, and pathogen-vectorhost interactions require further characterization.

\section{FUTURE PROSPECTS AND STRATEGIES FOR ZC RESISTANCE}

In the past, lack of advanced genomic tools, combined with the cost effectiveness of chemical control strategies led to heavy reliance on pesticides, rather than prioritizing the development of new resistance varieties to pests/pathogens (Rowe, 1992; Spooner and Bamberg, 1994). However, recent advances in genomics and genetics resources (Varshney et al., 2005; Broekgaarden et al., 2011) including those for potato ${ }^{1}$, should help in identifying desirable traits, alleles, and marker development to develop new ZC resistance cultivars. For instance, the availability of the potato reference genome sequence, the discovery of SNPs in elite North American potato germplasm and the development of the Infinium 8,303 potato array have helped in identification of genes linked to improved agronomic traits (Hamilton et al., 2011; Massa et al., 2011; Felcher et al., 2012). The resources also enabled marker-assisted selection (MAS), which helps identify markers tightly linked to a target locus, instead of relying on phenotypic selection alone in making selections for crosses. Thus, MAS can be used to accelerate introgression of desirable ZC tolerance traits from various potato breeding clones or wild species into cultivar development. Several studies showed the potential of improving potato traits by increasing heterozygosity and genetic diversity of parental clones (Mendoza and Haynes, 1974; Bradshaw and Ramsay, 2005; Jansky and Peloquin, 2006). Thus, more focus will need to be given for identification and introgression of alleles from a diverse pool of genetic resources, including wild species, landraces, and cultivated potatoes (Bethke et al., 2019).

Introgression of desirable traits from related or distant species to cultivated potatoes using genetic engineering (GE)

\footnotetext{
${ }^{1}$ http://solcap.msu.edu/; https://www.polyploids.org/
}

can be a viable alternative to speed cultivar development and reduce introgression of undesirable genetic material or traits (Halterman et al., 2016). Few example, GE potatoes that received United States regulatory approval include the "NewLeaf" Bt potatoes for resistance against Colorado beetle (Leptinotarsa decemlineata), "Innate ${ }^{\mathrm{TM}}$ " potatoes with resistance to fungal disease (late blight) and acrylamide formation ${ }^{2}$ (Halterman et al., 2016). Despite the significant advantages of GE crops, the costs associated with $\mathrm{R} \& \mathrm{D}$ and regulatory approval is tremendous and necessitates private sector investments, or public-private partnership. Furthermore, the GE products face marketing hurdles due to public skepticism (Halterman et al., 2016).

Selected traits can also be modified/introduced by genome editing technologies such as TALEN or CRISPR-Cas9 without introducing new foreign DNA (Wolt et al., 2016; Hameed et al., 2018). Derived plant products potentially face less regulatory scrutiny and approval burden. For instance, the United States regulatory body (USDA APHIS) determined that several transgene-free, genome-edited potato plants with disease resistance and other superior agronomic traits, would not be considered regulated under 7 CFR part 340 (Wolt et al., 2016). Although this does not preclude regulation by other agencies world-wide, it is nevertheless a significant advantage when it comes to commercialization.

\section{CONCLUSION}

Since its first report in 1994, ZC disease is now established in several potato producing regions worldwide. The putative causal agent, CLso, can also infect other economically significant Solanaceae crops, thus posing an even more threat to the agricultural industry. IPM strategies (chemical, cultural, and biological control) have been implemented to manage psyllid vector population and limit ZC disease. However, we still need long-term solutions. Recent developments in potato genetic resources and crop improvement technologies could be further leveraged for developing new potato cultivars with genetic resistance to the psyllid and/or CLso. In combination with IPM practices, the $\mathrm{ZC}$ resistant or tolerant cultivars could be deployed in the future to effectively manage $\mathrm{ZC}$ disease.

\section{AUTHOR CONTRIBUTIONS}

KM supervised the study. All others contributed to the preparation and editing of the review.

\section{FUNDING}

This study was supported by funds from Texas A\&M AgriLife Research Insect-Vectored Disease Seed Grant (124190-96210), USDA-NIFA-AFRI (2018-70016-28198; HATCH 1023984), and Foundation for Food and Agricultural Research New Innovator Award (534299) to KM.

\footnotetext{
${ }^{2}$ https://apnews.com/article/1d3c790ad18f4e828598ccf44ec047bf
} 


\section{REFERENCES}

Aguilar, E., Sengoda, V., Bextine, B., Mccue, K., and Munyaneza, J. (2013). First report of "Candidatus Liberibacter solanacearum" on tobacco in Honduras. Plant Dis. 97, 1376-1376. doi: 10.1094/pdis-04-13-0453-pdn

Al-Jabr, A. M. (1999). Integrated Pest Management of Tomato/Potato Psyllid, Paratrioza Cockerelli (Sulc)(Homoptera: Psyllidae) with Emphasis on its Importance in Greenhouse Grown Tomatoes. United States: Colorado State University.

Ananthakrishnan, G., Choudhary, N., Roy, A., Sengoda, V., Postnikova, E., Hartung, J., et al. (2013). Development of primers and probes for genus and species specific detection of 'Candidatus Liberibacter species' by real-time PCR. Plant Dis. 97, 1235-1243. doi: 10.1094/pdis-12-12-1174-re

Arslan, A., Bessey, P. M., Matsuda, K., and Oebker, N. F. (1985). Physiological effects of psyllid (Paratrioza cockerelli) on potato. Am. Potato J. 62, 9-22. doi: $10.1007 / \mathrm{bf} 02871295$

Avila, C. A., Marconi, T. G., Viloria, Z., Kurpis, J., and Del Rio, S. Y. (2019). Bactericera cockerelli resistance in the wild tomato Solanum habrochaites is polygenic and influenced by the presence of Candidatus Liberibacter solanacearum. Sci. Rep. 9, 1-11.

Beard, S. S., Pitman, A. R., Kraberger, S., and Scott, I. A. W. (2013). SYBR Green real-time quantitative PCR for the specific detection and quantification of 'Candidatus Liberibacter solanacearum' in field samples from New Zealand. Eur. J. Plant Pathol. 136, 203-215. doi: 10.1007/s10658-012-0156-5

Beard, S. S., and Scott, I. A. (2013). A rapid method for the detection and quantification of the vector-borne bacterium 'Candidatus Liberibacter solanacearum' in the tomato potato psyllid, Bactericera cockerelli. Entomol. Exp. Appl. 147, 196-200. doi: 10.1111/eea.12056

Bethke, P. C., Halterman, D. A., and Jansky, S. (2017). Are we getting better at using wild potato species in light of new tools? Crop Sci. 57, 1241-1258. doi: 10.2135/cropsci2016.10.0889

Bethke, P. C., Halterman, D. A., and Jansky, S. H. (2019). Potato germplasm enhancement enters the genomics era. Agron. J. 9:575. doi: 10.3390/ agronomy9100575

Bextine, B., Aguilar, E., Rueda, A., Caceres, O., Sengoda, V., Mccue, K., et al. (2013). First report of "Candidatus Liberibacter solanacearum" on tomato in El Salvador. Plant Dis. 97, 1245-1245. doi: 10.1094/pdis-03-13-0248-pdn

Borges, K. M., Cooper, W. R., Garczynski, S. F., Thinakaran, J., Jensen, A. S., Horton, D. R., et al. (2017). "Candidatus Liberibacter solanacearum” associated with the psyllid, Bactericera maculipennis (Hemiptera: Triozidae). Environ. Entomol. 46, 210-216.

Bradshaw, J. E., and Ramsay, G. (2005). Utilisation of the commonwealth potato collection in potato breeding. Euphytica 146, 9-19. doi: 10.1007/s10681-0053881-4

Broekgaarden, C., Snoeren, T. A., Dicke, M., and Vosman, B. (2011). Exploiting natural variation to identify insect-resistance genes. Plant Biotechnol. J. 9, 819-825. doi: 10.1111/j.1467-7652.2011.00635.x

Buchman, J. L., Heilman, B. E., and Munyaneza, J. E. (2011). Effects of liberibacterinfective Bactericera cockerelli (Hemiptera: Triozidae) density on zebra chip potato disease incidence, potato yield, and tuber processing quality. J. Econ. Entomol. 104, 1783-1792. doi: 10.1603/ec11146

Butler, C. D., Gonzalez, B., Manjunath, K. L., Lee, R. F., Novy, R. G., Miller, J. C., et al. (2011). Behavioral responses of adult potato psyllid, Bactericera cockerelli (Hemiptera: Triozidae), to potato germplasm and transmission of Candidatus Liberibacter psyllaurous. J. Crop Prot. 30, 1233-1238. doi: 10.1016/j.cropro. 2011.05.006

Butler, C. D., and Trumble, J. T. (2012). The potato psyllid, Bactericera cockerelli (Sulc)(Hemiptera: Triozidae): life history, relationship to plant diseases, and management strategies. Terr. Arthropod. Rev. 5, 87-111. doi: 10.1163/ $187498312 \times 634266$

Carrillo, C. C., Fu, Z., and Burckhardt, D. (2019). First record of the tomato potato psyllid Bactericera cockerelli from South America. Bull. Insectol. 72, 85-91.

Carter, W. (1939). Injuries to plants caused by insect toxins. Bot. Rev. 5:273. doi: $10.1007 /$ bf02878504

Charkowski, A., Sharma, K., Parker, M. L., Secor, G. A., and Elphinstone, J. (2020). "Bacterial diseases of potato" in The Potato Crop. eds H. Campos, O. Ortiz. (Germany: Springer). 351-388. doi: 10.1007/978-3-030-28683-5_10
Chávez, E. C., Bautista, O. H., Flores, J. L., Uribe, L. A., and Fuentes, Y. M. O. (2015). Insecticide-resistance ratios of three populations of Bactericera cockerelli (Hemiptera: Psylloidea: Triozidae) in regions of northern Mexico. Fla. Entomol. 98, 950-953. doi: 10.1653/024.098.0322

Contreras-Rendón, A., Sánchez-Pale, J. R., Fuentes-Aragón, D., Alanís-Martínez, I., and Silva-Rojas, H. V. (2020). Conventional and qPCR reveals the presence of 'Candidatus Liberibacter solanacearum'haplotypes A, and B in Physalis philadelphica plant, seed, and Bactericera cockerelli psyllids, with the assignment of a new haplotype H in Convolvulaceae. Antonie Van Leeuwenhoek 113, 533-551. doi: 10.1007/s10482-019-01362-9

Cranshaw, W. (1994). "The potato (tomato) psyllid, Paratrioza cockerelli (Sulc), as a pest of potatoes" in Advances in Potato Pest Biology and Management. eds G.W. Zehnder, M.L. Powelson, R.K. Hansson, and K.V. Raman. (St. Paul, MN: APS Press). 83-95.

Crosslin, J., Hamm, P., Eggers, J., Rondon, S., Sengoda, V., and Munyaneza, J. (2012). First report of zebra chip disease and "Candidatus Liberibacter solanacearum" on potatoes in Oregon and Washington State. Plant Dis. 96, 452. doi: 10.1094/pdis-10-11-0894

Delgado, L., Schuster, M., and Torero, M. (2020). Quantity and quality food losses across the value chain: a comparative analysis. Food Policy 98:101958. doi: 10.1016/j.foodpol.2020.101958

Diaz-Montano, J., Vindiola, B. G., Drew, N., Novy, R. G., Miller, J. C., and Trumble, J. T. (2014). Resistance of selected potato genotypes to the potato psyllid (Hemiptera: Triozidae). Am. J. Pot. Res. 91, 363-367. doi: 10.1007/s12230-0139356-6

Dicke, M., and Van Poecke, R. M. (2002). Signalling in plant-insect interactions: signal transduction in direct and indirect plant defence. J. Signal Transduct. 289:316.

Douches, D., Maas, D., Jastrzebski, K., and Chase, R. (1996). Assessment of potato breeding progress in the USA over the last century. Crop Sci. 36, 1544-1552. doi: $10.2135 /$ cropsci1996.0011183x003600060024x

Faostat, F. (2020). FAOSTAT. Available online at: http://www.fao.org/faostat/en/ \#data/QC [Accessed May 04, 2020]

Farber, C., Sanchez, L., Pant, S., Scheuring, D., Vales, I., Mandadi, K., et al. (2021). Potential of spatially offset Raman Spectroscopy for detection of Zebra Chip and Potato Virus Y diseases of potatoes (Solanum tuberosum). ACS Agric. Sci. Technol. 1, 211-221. doi: 10.1021/acsagscitech.1c00024

Felcher, K. J., Coombs, J. J., Massa, A. N., Hansey, C. N., Hamilton, J. P., Veilleux, R. E., et al. (2012). Integration of two diploid potato linkage maps with the potato genome sequence. PLoS One 7:e36347. doi: 10.1371/journal.pone. 0036347

Fife, A. N., Cruzado, K., Rashed, A., Novy, R. G., and Wenninger, E. J. (2020). Potato Psyllid (Hemiptera: Triozidae) Behavior on Three Potato Genotypes With Tolerance to 'Candidatus Liberibacter solanacearum'. J. Insect Sci. 20:15.

Goolsby, J. A., Adamczyk, J., Bextine, B., Lin, D., Munyaneza, J. E., and Bester, G. (2007). Development of an IPM program for management of the potato psyllid to reduce incidence of zebra chip disorder in potatoes. Subtrop. Plant Sci. 59, 85-94.

Grimm, K. D. S., Mustafa, T., Cooper, W. R., and Munyaneza, J. E. (2018). Role of 'Candidatus Liberibacter solanacearum'and Bactericera cockerelli haplotypes in zebra chip incidence and symptom severity. Am. J. Potato Res. 95, 709-719. doi: $10.1007 / \mathrm{s} 12230-018-9678-5$

Guenthner, J., Goolsby, J., and Greenway, G. (2012). Use and cost of insecticides to control potato psyllids and zebra chip on potatoes. Southwest. Entomol. 37, 263-268. doi: 10.3958/059.037.0302

Haapalainen, M., Latvala, S., Wickström, A., Wang, J., Pirhonen, M., and Nissinen, A. I. (2020). A novel haplotype of 'Candidatus Liberibacter solanacearum'found in Apiaceae and Polygonaceae family plants. Eur. J. Plant Pathol. 156, 413-423. doi: 10.1007/s10658-019-01890-0

Haapalainen, M., Wang, J., Latvala, S., Lehtonen, M. T., Pirhonen, M., and Nissinen, A. (2018). Genetic variation of 'Candidatus Liberibacter solanacearum'haplotype $\mathrm{C}$ and identification of a novel haplotype from Trioza urticae and stinging nettle. Phytopathology 108, 925-934. doi: 10.1094/phyto12-17-0410-r

Halterman, D., Guenthner, J., Collinge, S., Butler, N., and Douches, D. (2016). Biotech potatoes in the 21st century: 20 years since the first biotech potato. Am. J. Pot. Res. 93, 1-20. doi: 10.1007/s12230-015-9485-1 
Hameed, A., Zaidi, S. S.-E.-A., Shakir, S., and Mansoor, S. (2018). Applications of new breeding technologies for potato improvement. Front. Plant Sci. 9:925. doi: $10.3389 /$ fpls.2018.00925

Hamilton, J. P., Hansey, C. N., Whitty, B. R., Stoffel, K., Massa, A. N., Van Deynze, A., et al. (2011). Single nucleotide polymorphism discovery in elite North American potato germplasm. BMC Genom. 12:302. doi: 10.1186/1471-2 164-12-302

Hansen, A. K., Trumble, J., Stouthamer, R., and Paine, T. (2008). A new huanglongbing species, "Candidatus Liberibacter psyllaurous," found to infect tomato and potato, is vectored by the psyllid Bactericera cockerelli (Sulc). Appl. Environ. Microbiol. 74, 5862-5865. doi: 10.1128/aem.01268-08

Harrison, K., Tamborindeguy, C., Scheuring, D. C., Herrera, A. M., Silva, A., Badillo-Vargas, I. E., et al. (2019). Differences in Zebra Chip severity between 'Candidatus Liberibacter solanacearum'haplotypes in Texas. Am. J. Potato Res. 96, 86-93. doi: 10.1007/s12230-018-9692-7

Henne, D., Paetzold, L., Workneh, F., and Rush, C. (2010). "Evaluation of potato psyllid cold tolerance, overwintering survival, sticky trap sampling, and effects of Liberibacter on potato psyllid alternate host plants" in Proceedings 10th Annual Zebra Chip Reporting Session. (Dallas: Hyatt DFW Airport).

Henrickson, A., Kalischuk, M., Lynn, J., Meers, S., Johnson, D., and Kawchuk, L. (2019). First report of zebra chip on potato in Canada. Plant Dis. 103, 1016-1016. doi: 10.1094/pdis-09-18-1576-pdn

Hernández-Deheza, M. G., Rojas-Martínez, R. I., Rivera-Peña, A., Zavaleta-Mejía, E., Ochoa-Martínez, D. L., and Carrillo-Salazar, A. (2018). Resistance in potato to two haplotypes of 'Candidatus Liberibacter solanacearum'. Plant Pathol. J. 100, 191-196. doi: 10.1007/s42161-018-0046-6

Hirsch, C. N., Hirsch, C. D., Felcher, K., Coombs, J., Zarka, D., Van Deynze, A., et al. (2013). Retrospective view of North American potato (Solanum tuberosum L.) breeding in the 20th and 21 st centuries. G3 3, 1003-13. doi: 10.1534/g3.113. 005595

Horton, D. R., Cooper, W. R., Munyaneza, J. E., Swisher, K. D., Echegaray, E. R., Murphy, A. F., et al. (2015). A new problem and old questions: potato psyllid in the Pacific Northwest. Am. Entomol. 61, 234-244. doi: 10.1093/ae/tmv047

Jansky, S., Dempewolf, H., Camadro, E. L., Simon, R., Zimnoch-Guzowska, E., Bisognin, D., et al. (2013). A case for crop wild relative preservation and use in potato. Crop Sci. 53, 746-754. doi: 10.2135/cropsci2012.11.0627

Jansky, S. H., and Peloquin, S. J. (2006). Advantages of wild diploid Solanum species over cultivated diploid relatives in potato breeding programs. Genet. Resour. Crop Evol. 53, 669-674. doi: 10.1007/s10722-004-2949-7

Kogan, M., and Ortman, E. F. (1978). Antixenosis-a new term proposed to define Painter's "nonpreference" modality of resistance. Bull. Ecol. Soc. Am. 24, 175-176. doi: 10.1093/besa/24.2.175

Lacey, L., Liu, T.-X., Buchman, J., Munyaneza, J., Goolsby, J., and Horton, D. (2011). Entomopathogenic fungi (Hypocreales) for control of potato psyllid, Bactericera cockerelli (Šulc)(Hemiptera: Triozidae) in an area endemic for zebra chip disease of potato. Biol. Control 56, 271-278. doi: 10.1016/j.biocontrol.2010. 11.012

Liefting, L., Perez-Egusquiza, Z., Clover, G., and Anderson, J. (2008a). A new 'Candidatus Liberibacter'species in Solanum tuberosum in New Zealand. Plant Dis. 92, 1474-1474. doi: 10.1094/pdis-92-10-1474a

Liefting, L., Ward, L., Shiller, J., and Clover, G. (2008b). A new 'Candidatus Liberibacter'species in Solanum betaceum (tamarillo) and Physalis peruviana (cape gooseberry) in New Zealand. Plant Dis. 92, 1588-1588. doi: 10.1094/pdis92-11-1588b

Liefting, L. W., Sutherland, P. W., Ward, L. I., Paice, K. L., Weir, B. S., and Clover, G. R. (2009). A new 'Candidatus Liberibacter'species associated with diseases of solanaceous crops. Plant Dis. 93, 208-214. doi: 10.1094/pdis-93-3-0208

Linford, M. (1928). Psyllid-yellows (cause undetermined). Plant Dis. Rep. Suppl. 59, 95-99.

MacDonald, F., Walker, G., Larsen, N., and Wallace, A. (2010). Naturally occurring predators of Bactericera cockerelli in potatoes. N. Z. Plant Prot. 63, 275-275. doi: 10.30843/nzpp.2010.63.6583

Machida-Hirano, R. (2015). Diversity of potato genetic resources. Breed. sci. 65, 26-40. doi: 10.1270/jsbbs.65.26

Massa, A. N., Childs, K. L., Lin, H., Bryan, G. J., Giuliano, G., and Buell, C. R. (2011). The transcriptome of the reference potato genome Solanum tuberosum Group Phureja clone DM1-3 516R44. PLoS One 6:e26801. doi: 10.1371/journal. pone.0026801
Mauchline, N., and Stannard, K. (2013). Evaluation of selected entomopathogenic fungi and bioinsecticides against Bactericera cockerelli (Hemiptera). N. Z. Plant Prot. 66, 324-332. doi: 10.30843/nzpp.2013.66.5707

Mauck, K. E., Sun, P., Meduri, V. R., and Hansen, A. K. (2019). New Ca. Liberibacter psyllaurous haplotype resurrected from a 49-year-old specimen of Solanum umbelliferum: a native host of the psyllid vector. Sci. Rep. 9, 1-13.

Mendoza, H., and Haynes, F. (1974). Genetic basis of heterosis for yield in the autotetraploid potato. Theor. Appl. Genet. 45, 21-25. doi: 10.1007/bf 00281169

Mendoza-Herrera, A., Levy, J., Harrison, K., Yao, J., Ibanez, F., and Tamborindeguy, C. (2018). Infection by Candidatus Liberibacter solanacearum'haplotypes A and B in Solanum lycopersicum 'Moneymaker'. Plant Dis. 102, 2009-2015. doi: 10.1094/pdis-12-17-1982-re

Merfield, C., Geary, I., Hale, R., and Hodge, S. (2015). Field evaluation of the effectiveness of mesh crop covers for the protection of potatoes from tomato potato psyllid. N. Z. J. Crop Hortic. Sci. 43, 123-133. doi: 10.1080/01140671. 2015.1015576

Monger, W. A., and Jeffries, C. J. (2018). A survey of 'Candidatus Liberibacter solanacearum'in historical seed from collections of carrot and related Apiaceae species. Eur. J. Plant Pathol. 150, 803-815. doi: 10.1007/s10658-017-1322-6

Munyaneza, J., Buchman, J., Heilman, B., Sengoda, V., and Henne, D. (2011). "Effects of zebra chip and potato psyllid on potato seed quality" in 11th Annual Zebra Chip Reporting Session. (TX: San Antonio)6-9.

Munyaneza, J., Crosslin, J., and Upton, J. (2007). Association of Bactericera cockerelli (Homoptera: Psyllidae) with "zebra chip," a new potato disease in southwestern United States and Mexico. J. Econ. Entomol. 100, 656-663. doi: 10.1093/jee/100.3.656

Munyaneza, J., Fisher, T., Sengoda, V., Garczynski, S., Nissinen, A., and Lemmetty, A. (2010). First report of "Candidatus Liberibacter solanacearum" associated with psyllid-affected carrots in Europe. Plant Dis. 94:639. doi: 10.1094/pdis94-5-0639a

Munyaneza, J., Sengoda, V., Aguilar, E., Bextine, B., and Mccue, K. (2013). First report of 'Candidatus Liberibacter solanacearum' infecting eggplant in Honduras. Plant Dis. 97, 1654-1654. doi: 10.1094/pdis-06-13-0641-pdn

Munyaneza, J., Sengoda, V., Aguilar, E., Bextine, B., and Mccue, K. (2014). First report of 'Candidatus Liberibacter solanacearum'on pepper in Honduras. Plant Dis. 98, 154-154. doi: 10.1094/pdis-06-13-0598-pdn

Munyaneza, J., Sengoda, V., Crosslin, J., Garzon-Tiznado, J., and CardenasValenzuela, O. (2009). First report of "Candidatus Liberibacter solanacearum" in tomato plants in Mexico. Plant Dis. 93, 1076-1076. doi: 10.1094/pdis-93-10$1076 a$

Munyaneza, J. E. (2012). Zebra chip disease of potato: biology, epidemiology, and management. Am. J. Pot. Res. 89, 329-350. doi: 10.1007/s12230-0129262-3

Murphy, A., Cating, R., Goyer, A., Hamm, P., and Rondon, S. (2014). First report of natural infection by 'Candidatus Liberibacter solanacearum'in bittersweet nightshade (Solanum dulcamara) in the Columbia Basin of Eastern Oregon. Plant Dis. 98, 1425-1425. doi: 10.1094/pdis-05-14-0497-pdn

Murphy, A. F., Rondon, S. I., and Jensen, A. S. (2013). First report of potato psyllids, Bactericera cockerelli, overwintering in the Pacific Northwest. Am. J. Pot. Res. 90, 294-296. doi: 10.1007/s12230-012-9281-0

Nelson, W. R., Fisher, T. W., and Munyaneza, J. E. (2011). Haplotypes of "Candidatus Liberibacter solanacearum" suggest long-standing separation. Eur. J. Plant Pathol. 130, 5-12. doi: 10.1007/s10658-010-9737-3

Nelson, W. R., Sengoda, V. G., Alfaro-Fernandez, A. O., Font, M. I., Crosslin, J. M., and Munyaneza, J. E. (2013). A new haplotype of "Candidatus Liberibacter solanacearum” identified in the Mediterranean region. Eur. J. Plant Pathol. 135, 633-639. doi: 10.1007/s10658-012-0121-3

Nuñez, J. H. D., Aegerter, B. J., Baldwin, R. A., Westerdahl, B. B., Trumble, J. T., and Wilson, R. G. (2019). UC IPM Pest Management Guidelines: Potato. United States: University of California.

Painter, R. H. (1951). Insect Resistance in Crop Plants. United States: LWW.

Pitman, A. R., Drayton, G. M., Kraberger, S. J., Genet, R. A., and Scott, I. A. (2011). Tuber transmission of 'Candidatus Liberibacter solanacearum' and its association with zebra chip on potato in New Zealand. Euro. J. Plant Patho. 129, 389-398. doi: 10.1007/s10658-010-9702-1

Pletsch, D. J. (1947). The potato psyllid, Paratrioza cockerelli (Sulc), its biology and control. Bull. Mont. agric. Exp. Stn. 446:95. 
PM. (2017). 9/25 (1) Bactericera cockerelli and 'Candidatus Liberibacter solanacearum'. EPPO Bull. 47, 513-523. doi: 10.1111/epp.12442

Prager, S. M., Vindiola, B., Kund, G. S., Byrne, F. J., and Trumble, J. T. (2013). Considerations for the use of neonicotinoid pesticides in management of Bactericera cockerelli (Šulk)(Hemiptera: Triozidae). J. Crop Prot. 54, 84-91. doi: 10.1016/j.cropro.2013.08.001

Rashidi, M., Novy, R. G., Wallis, C. M., and Rashed, A. (2017). Characterization of host plant resistance to zebra chip disease from species-derived potato genotypes and the identification of new sources of zebra chip resistance. PLoS One:12:e0183283. doi: 10.1371/journal.pone.0183283

Richards, B. (1928). A new and destructive disease of the potato in Utah and its relation to the potato psylla. Phytopathology 18, 140-141.

Richards, B., and Blood, H. (1933). Psyllid yellows of the potato. J. Agric. Res. 46, 189-216.

Rojas, P., Rodríguez-Leyva, E., Lomeli-Flores, J. R., and Liu, T.-X. (2015). Biology and life history of Tamarixia triozae, a parasitoid of the potato psyllid Bactericera cockerelli. Biol. Control 60, 27-35. doi: 10.1007/s105 26-014-9625-4

Rosson, P., Niemeyer, M., Palma, M., and Ribera, L. (2006). Economic Impacts of Zebra Chips on the Texas Potato Industry center for North American Studies. United States: Texas A\&M University.

Rowe, R. C. (1992). Future challenges in managing potato health. Am. Potato J. 69, 769-775. doi: $10.1007 / \mathrm{bf} 02853818$

Rubio-Covarrubias, O., Cadena-Hinojosa, M., Prager, S., Wallis, C., and Trumble, J. (2017). Characterization of the tolerance against zebra chip disease in tubers of advanced potato lines from Mexico. Am. J. Pot. Res. 94, 342-356. doi: 10.1007/s12230-017-9570-8

Savary, S., Willocquet, L., Pethybridge, S. J., Esker, P., Mcroberts, N., and Nelson, A. (2019). The global burden of pathogens and pests on major food crops. Nat. Ecol. Evol. 3, 430-439. doi: 10.1038/s41559-018-0793-y

Secor, G., Rivera, V., Abad, J., Lee, I.-M., Clover, G., Liefting, L., et al. (2009). Association of 'Candidatus Liberibacter solanacearum'with zebra chip disease of potato established by graft and psyllid transmission, electron microscopy, and PCR. Plant Dis. 93, 574-583. doi: 10.1094/pdis-93-6-0574

Secor, G. A., and Rivera-Varas, V. V. (2004). Emerging diseases of cultivated potato and their impact on Latin America. Rev. Latinoamericana Papa 1, 1-8.

Sengoda, V. G., Buchman, J. L., Henne, D. C., Pappu, H. R., and Munyaneza, J. E. (2013). "Candidatus Liberibacter solanacearum" titer over time in Bactericera cockerelli (Hemiptera: Triozidae) after acquisition from infected potato and tomato plants. J. Econ. Entomol. 106, 1964-1972. doi: 10.1603/ec13129

Smith, C. M. (2005). Plant Resistance to Arthropods: Molecular and Conventional Approaches. Netherlands: Springer.

Spooner, D. M., and Bamberg, J. B. (1994). Potato genetic resources: sources of resistance and systematics. Am. J. Bot. 71, 325-337. doi: 10.1007/bf02849059

Spooner, D. M., Ghislain, M., Simon, R., Jansky, S. H., and Gavrilenko, T. (2014). Systematics, diversity, genetics, and evolution of wild and cultivated potatoes. Bot. Rev. 80, 283-383. doi: 10.1007/s12229-014-9146-y

Šulc, K. (1909). Trioza cockerelli, a novelty from North America, being also of economic importance. Acta Soc. Entomol. Bohem. 6, 102-108.

Sumner-Kalkun, J. C., Highet, F., Arnsdorf, Y. M., Back, E., Carnegie, M., Madden, S., et al. (2020). 'Candidatus Liberibacter solanacearum'distribution and diversity in Scotland and the characterisation of novel haplotypes from Craspedolepta spp.(Psyllidae: Aphalaridae). Sci. Rep. 10, 1-11. doi: 10.1007/9783-319-23534-9_1

Swisher, K. D., Munyaneza, J. E., and Crosslin, J. M. (2012). High resolution melting analysis of the cytochrome oxidase I gene identifies three haplotypes of the potato psyllid in the United States. Environ. Entomol. 41, 1019-1028. doi: 10.1603/en12066

Swisher, K. D., Sengoda, V. G., Dixon, J., Munyaneza, J. E., Murphy, A. F., Rondon, S. I., et al. (2014). Assessing potato psyllid haplotypes in potato crops in the Pacific Northwestern United States. Am. J. Potato Res. 91, 485-491. doi: 10. 1007/s12230-014-9378-8
Swisher Grimm, K., and Garczynski, S. (2019). Identification of a new haplotype of 'Candidatus Liberibacter solanacearum'in Solanum tuberosum. Plant Dis. 103, 468-474.

Szczepaniec, A., Varela, K. A., Kiani, M., Paetzold, L., and Rush, C. M. (2019). Incidence of resistance to neonicotinoid insecticides in Bactericera cockerelli across Southwest US. J. Crop Prot. 116, 188-195. doi: 10.1016/j.cropro.2018. 11.001

Teresani, G. R., Bertolini, E., Alfaro-Fernández, A., Martínez, C., Tanaka, F. A. O., Kitajima, E. W., et al. (2014). Association of 'Candidatus Liberibacter solanacearum'with a vegetative disorder of celery in Spain and development of a real-time PCR method for its detection. Phytopathology 104, 804-811. doi: 10.1094/phyto-07-13-0182-r

Teulon, D., Workman, P., Thomas, K., and Nielsen, M. (2009). Bactericera cockerelli incursion dispersal and current distribution on vegetable crops in New Zealand. N. Z. Plant Prot. 62, 136-144. doi: 10.30843/nzpp.2009.62.4783

Thomas, J., Geering, A., and Maynard, G. (2018). Detection of "Candidatus Liberibacter solanacearum" in tomato on Norfolk Island. Australia. Australas. Plant Dis. Notes 13:7.

USDA, N. (2019). Potatoes 2018 Summary. United States: USDA.

Varshney, R. K., Graner, A., and Sorrells, M. E. (2005). Genomics-assisted breeding for crop improvement. Trends Plant Sci. 10, 621-630. doi: 10.1016/j.tplants. 2005.10.004

Vereijssen, J., Smith, G. R., and Weintraub, P. G. (2018). Bactericera cockerelli (Hemiptera: Triozidae) and Candidatus Liberibacter solanacearum in potatoes in New Zealand: biology, transmission, and implications for management. J. Integr. Pest Manag. 9:13.

Vereijssen, J., Taylor, N., Barnes, A., Thompson, S., Logan, D., Butler, R., et al. (2015). First report of 'Candidatus Liberibacter solanacearum'in Jerusalem cherry (Solanum pseudocapsicum) and thorn-apple (Datura stramonium) in New Zealand. New Dis. Rep. 32:5197.

Walker, G., Macdonald, F., Larsen, N., and Wallace, A. (2011). Monitoring Bactericera cockerelli and associated insect populations in potatoes in South Auckland. N. Z. Plant Prot. 64, 269-275. doi: 10.30843/nzpp.2011.64. 6009

Wallis, R. L. (1955). Ecological Studies on the Potato Psyllid as a Pest of Potatoes. Washington: D.C.

War, A. R., Paulraj, M. G., Ahmad, T., Buhroo, A. A., Hussain, B., Ignacimuthu, S., et al. (2012). Mechanisms of plant defense against insect herbivores. Plant Signal. Behav. 7, 1306-1320. doi: 10.4161/psb.21663

Wen, A., Mallik, I., Alvarado, V., Pasche, J., Wang, X., Li, W., et al. (2009). Detection, distribution, and genetic variability of 'Candidatus Liberibacter'species associated with zebra complex disease of potato in North America. Plant Dis. 93, 1102-1115. doi: 10.1094/pdis-93-11-1102

Wolt, J. D., Wang, K., and Yang, B. (2016). The regulatory status of genome-edited crops. Plant Biotech. J. 14, 510-518. doi: 10.1111/pbi. 12444

Yao, J., Saenkham, P., Levy, J., Ibanez, F., Noroy, C., Mendoza, A., et al. (2016). Interactions "Candidatus Liberibacter solanacearum"-Bactericera cockerelli: haplotype effect on vector fitness and gene expression analyses. Front. Cell. Infect. Microbiol. 6:62. doi: 10.3389/fcimb.2016.00062

Conflict of Interest: The authors declare that the research was conducted in the absence of any commercial or financial relationships that could be construed as a potential conflict of interest.

Copyright (๑) 2021 Mora, Ramasamy, Damaj, Irigoyen, Ancona, Ibanez, Avila and Mandadi. This is an open-access article distributed under the terms of the Creative Commons Attribution License (CC BY). The use, distribution or reproduction in other forums is permitted, provided the original author(s) and the copyright owner $(s)$ are credited and that the original publication in this journal is cited, in accordance with accepted academic practice. No use, distribution or reproduction is permitted which does not comply with these terms. 